\title{
Blending biodiesel in fishing boat fuels for improved fuel characteristics
}

\author{
Cherng-Yuan Lin* \\ Department of Marine Engineering, National Taiwan Ocean University, Keelung, Taiwan
}

Edited by:

Junfeng Rong, Research Institute of

Petroleum Processing, China

Reviewed by:

Jun Yong Zhu, Forest Products

Laboratory, USA

Xuebing Zhao, Tsinghua University,

China

${ }^{*}$ Correspondence:

Cherng-Yuan Lin, Department of Marine Engineering, National Taiwan

Ocean University, Keelung 202,

Taiwan

e-mail:lin7108@ntou.edu.tw
Biodiesel is a renewable, clean, alternative energy source with advantages, such as excellent lubricity, superior biodegradability, and high combustion efficiency. Biodiesel is considered for mixing with fishing boat fuels to adjust their fuel characteristics so that toxic pollutants and greenhouse-effect gas emissions from such shipping might be reduced. The effects of blending fishing boat fuels $A$ and $B$ with various weight proportions of biodiesel are experimentally investigated in this study. The results show that biodiesel blending can significantly improve the inferior fuel properties of both fishing boat fuels and particularly fuel $B$. The flash points of both of these fuels increases significantly with the addition of biodiesel and thus enhances the safety of transporting and storing these blended fuels. The flash point of fishing boat fuel B even increases by $16 \%$ if $25 \mathrm{wt}$. \% biodiesel is blended. The blending of biodiesel with no sulfur content is found to be one of the most effective ways to reduce the high sulfur content of fishing boat fuel, resulting in a reduction in the emission of sulfur oxides. The addition of only $25 \mathrm{wt}$. \% biodiesel decreased the sulfur content of the fishing boat fuel by $37 \%$. The high kinematic viscosity of fishing boat fuel B was also observed to be reduced by $63 \%$ with the blending of just $25 \mathrm{wt}$. \% biodiesel. However, biodiesel blending caused a slight decrease in heating value around $1-4.5 \%$.

Keywords: fishing boat fuel, renewable energy, biodiesel property, emission reduction, sulfur content

\section{INTRODUCTION}

Fishing boat fuels A and B are distillate and residual fuels, respectively, refined from crude petroleum oil. Fishing boat fuel A, which is equivalent to ASTM No. 2D diesel, is frequently used for fishing boats powered by high- and medium-speed diesel engines sailing in coastal seas. In contrast, fishing boat fuel B, which is similar to ASTM No. 6 diesel and thus bears much inferior fuel characteristics to fishing boat fuel A, is generally used to propel fishing boats on the high seas. Compared with road-based diesel, the fuel quality of fishing boat fuel is poorer in order to save on fuel cost (Lin and Huang, 2012). For example, the sulfur content of fishing boat fuels A and B is much higher than that of super-low sulfur diesel (SLSD) with sulfur content of $10 \mathrm{ppm}$ maximum for on-road vehicles that may be as high as 1000 times that of SLSD. Moreover, about $10-20 \%$ of the world's oil is consumed in the waterborne transportation sector (Deniz et al., 2010). Hence, emissions from marine vessels are one of the significant sources of global air pollution and should not be continuously ignored (Eyring et al., 2005). It is estimated that the emissions from marine vessels account for about $4-9,14-31$, and $3-6 \%$ of the global sulfur oxides, nitrogen oxides, and carbon dioxide, respectively (Corett et al., 2007).

Blends of diesel fuel with various proportions of biodiesel have been widely applied as a clean alternative fuel for land-based transportation. For example, the European petro-diesel specifications allow up to B7 diesel (i.e., 7 vol.\% biodiesel in remaining petro-diesel) for diesel vehicles (European Committee for Standardization, 2009). The European Union (EU) 2003/30/EG directive requires that the blending ratio of biodiesel in petrodiesel be increased from 6 to 20\% by 2020 (European Biodiesel
Board, 2013). In addition, B5 is acceptable for on-road diesel vehicles in the U.S. (American Society for Testing and Materials, 2010a). The ASTM D7467 standard covers the specifications of B6-B20 blended diesel (American Society for Testing and Materials, 2010b). In contrast, the practical application of fishing boat fuel blended with biodiesel for use in fishing boats is rather limited, probably due to the relatively higher fuel cost of biodiesel.

Compared with petroleum-derived fishing boat fuel, biodiesel exhibits dominant fuel advantages in marine applications that include superior biodegradability, excellent lubricity to moving engine parts, a higher rate of complete combustion and a higher cetane number (Atadashi et al., 2010). Hence, the partial replacement of fishing boat fuel with biodiesel may enhance complete combustion, alleviate emission pollution from marine vessels, and protect the ecological environment and human health.

Emission pollution from the burning of fishing boat fuel with its degraded fuel properties might be reduced by blending these inferior fuels with biodiesel. Although biodiesel might provide benefits in combustion improvement and emission reduction, the application of biodiesel in marine industry is still very limited. Moreover, no experimental investigation on the fuel characteristics of blended fishing boat fuel with biodiesel has been found in the literature. Hence, variations in major fuel characteristics such as flash point and kinematic viscosity according to the weight proportions of biodiesel mixed with fishing boat fuels A and B are experimentally investigated in this study. The potential for using biodiesel as an alternative fuel for diesel engine-powered fishing boats is also evaluated. 


\section{EXPERIMENTAL DETAILS}

Fishing boat fuels A and B are the products of CPC Corporation in Taiwan. The biodiesel, made from waste cooking oil via the transesterification process with a strong alkali catalyst, was provided by Chant Oil Co., in Taiwan.

The amounts of heat released from burning the neat biodiesel and biodiesel-blended fishing boat fuels A and B were analyzed by an oxygen bomb calorimeter (automatic adiabatic model 1261; Parr Instrument Inc., USA). The flash points of the fuel samples were measured by a Pensky-Marten closed-cup flash point tester (model D-93; Shin-Kwang Machinery Inc., Taiwan). The carbon residue of the tested fuel in units of weight percentage was measured based on the following formula: weight of carbon residue left after the burning process/original weight of the tested fuel before burning. A specific gravity (SG) meter was used to measure the SG and density of the fuel samples at a constant temperature of $15^{\circ} \mathrm{C}$ based on the ASTM D-1298-99e2 standard test method (American Society for Testing and Materials, 2005). The gravity of American Petroleum Institute (API), G was then converted from the SG using the following formula:

$$
\mathrm{G}=141.5 / \mathrm{SG}-131.5 \text {. }
$$

The distillation temperatures of the test fuel samples were analyzed by a distillation temperature analyzer (model HAD-620; Petroleum Analyzer Inc., USA). $\mathrm{T}_{50}$ denotes the distillation temperature corresponding to $50 \mathrm{vol} . \%$ of the distilled, condensed, and collected liquid fuel in a test tube. The data of the API gravity $(G)$ and distillation temperature $T_{50}$ were used to calculate the cetane index $(\mathrm{CI})$ of the tested fuel based on the following formula (Pulkrabek, 2004):

$$
\begin{aligned}
\mathrm{CI}= & -420.34+0.016 \mathrm{G}^{2}+0.192 \mathrm{G}\left(\log \mathrm{T}_{50}\right) \\
& +65.01\left(\log \mathrm{T}_{50}\right)^{2}-0.0001809 \mathrm{~T}_{50}^{2}
\end{aligned}
$$

A capillary viscometer (model 501 23/IIc; Schott Gerate Inc., Germany) placed in a water tank at a constant temperature of $40^{\circ} \mathrm{C}$ was used to measure the kinematic viscosities of the tested fuels $\mathrm{A}$ and $\mathrm{B}$. The water content of the tested fuels was analyzed by a volumetric Karl Fischer Titration apparatus (model DL31; Mettler Toledo Inc., Switzerland).

The sulfur content of the tested fuels was determined by an inductively coupled plasma-atomic emission spectrometer (ICPAES) (model ICAP 9000; Jarrell-Ash Inc., USA). The ICP-AES is capable of simultaneously analyzing more than 80 elemental contents to a concentration of sub-ppb (parts per billion) in $60-300 \mathrm{~s}$.

\section{RESULTS AND DISCUSSION}

The fuel properties of the three base test fuels are shown in Table 1. Fishing boat fuel B was found to have significantly higher fuel sulfur content, density, carbon residue, flash point, and kinematic viscosity compared with those of fishing boat fuel A. In addition, fuel $B$ had a lower heating value than that of fuel $A$ and thus had a lower engine power output. This is primarily because fuel $\mathrm{B}$ is a residue fuel left over from the process of distilling petroleum oil,
Table 1 | Fuel properties of biodiesel and fishing boat fuels A and B.

\begin{tabular}{llccc}
\hline Fuel parameter & Unit & $\begin{array}{l}\text { Fishing } \\
\text { boat } \\
\text { fuel A }\end{array}$ & $\begin{array}{l}\text { Fishing } \\
\text { boat } \\
\text { fuel B }\end{array}$ & Biodiesel \\
\hline Cetane index & - & 68.43 & - & 45.51 \\
Sulfur content & $\mathrm{wt} \%$ & 0.293 & 0.951 & 0 \\
Heating value & $\mathrm{MJ} / \mathrm{kg}$ & 46.15 & 44.58 & 40.32 \\
Density (at 15 $\left.{ }^{\circ} \mathrm{C}\right)$ & $\mathrm{kg} / \mathrm{m}^{3}$ & 848 & 938 & 876 \\
Flash point & ${ }^{\circ} \mathrm{C}$ & 88 & 90 & 148 \\
Carbon residue & $\mathrm{wt} \%$ & 0.23 & 0.33 & 0.20 \\
Kinematic viscosity (at $\left.40^{\circ} \mathrm{C}\right)$ & $\mathrm{mm}{ }^{2} / \mathrm{s}$ & 3.77 & 54.64 & 5.97 \\
Acid number & $\mathrm{mg} \mathrm{KOH} / \mathrm{g}$ & - & - & 0.8
\end{tabular}

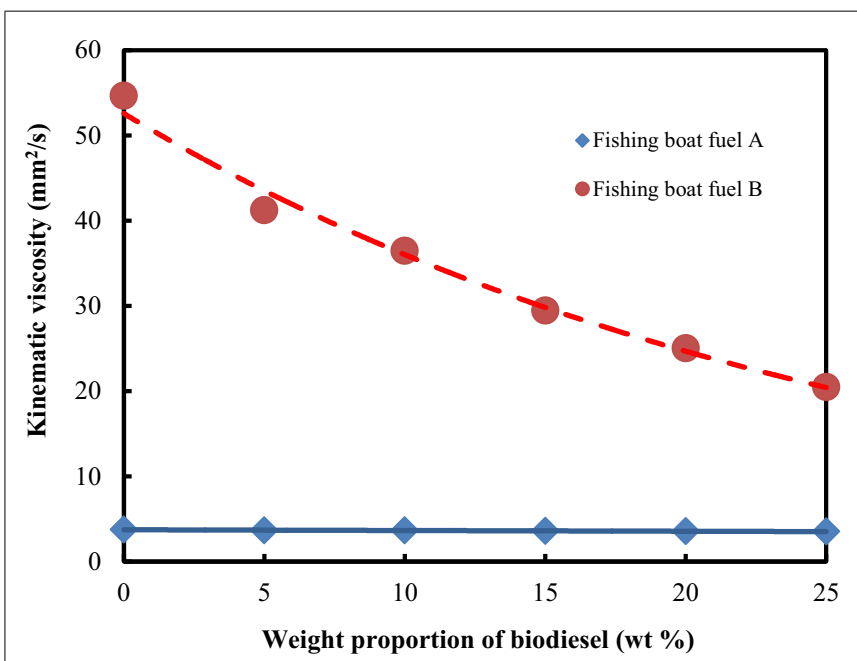

FIGURE 1 | Variation in kinematic viscosity according to the weight proportion of biodiesel-blended in fishing boat fuels $A$ and $B$.

whereas fuel $\mathrm{A}$ is a distillate fuel with properties similar to those of ASTM No. 2D diesel.

The kinematic viscosities of the blending of fishing boat fuel $\mathrm{B}$ with the biodiesel were found to decrease significantly according to the weight proportion of the biodiesel, as shown in Figure 1. This is attributed to the fact that fuel B bears considerably higher kinematic viscosity than biodiesel and fuel A. In contrast, the effect of biodiesel blending on the kinematic viscosity was not significant for fuel A due to the relatively lower difference of kinematic viscosity between the two fuels. The kinematic viscosity of fuel B could be reduced by $63 \%$ if as low as $25 \mathrm{wt} . \%$ biodiesel blending was used, decreasing the heating or pumping energy required for the residual fuel to achieve adequate fuel fluidity for higher atomization through an engine nozzle and, in turn, higher burning efficiency ( $\mathrm{Li}$ et al., 2013). In contrast, the kinematic viscosity of biodiesel is higher than diesel for road-based vehicles (briefly denoted as diesel). Hence, the kinematic viscosities of the diesel-biodiesel blends were found to increase as the percentage of biodiesel increased (Benjumea et al., 2008). Silitonga et al. (2013) experimentally observed that the kinematic viscosity of diesel fuel increased by $25.1 \%$ from 2.91 to $3.64 \mathrm{~mm}^{2} / \mathrm{s}$ if 30 vol. $\%$ refine palm 
oil biodiesel was blended with. Chen et al. (2013) also observed that the kinematic viscosity of the diesel - Jatropha curcas oil methyl esters (JME) blends increased linearly with volumetric percentage of the JME.

Figure 2 reveals that the flash points of the blended fishing boat fuels A and B were significantly increased with the increase in biodiesel blending weight ratios. Biodiesel, which is produced from the transesterification of vegetable oils, animal fats, algae oil or used cooking oil, generally has a much higher flash point than that of petroleum-derived diesel (Lin and Lin, 2012). The effect of biodiesel blending on the increase in the flash point was found to be more significant for fuel B than for fuel A, primarily owing to the higher flash point of fuel B. The flash point of the blended fuel $\mathrm{B}$ could be increased by $16 \%$ if $25 \mathrm{wt}$. \% biodiesel was added to the fuel (Figure 2). The safe transportation, storage, and use of fishing boat fuels would be greatly enhanced by using a blended fuel with a higher flash point (Mejia et al., 2013). In comparison with fishing boat fuels, the flash point of biodiesel-diesel for road-based vehicles blends increased at higher percentages of biodiesel (Shang et al., 2010). The flash point of diesel fuel increased by $18.2 \%$ from 71.5 to $84.5^{\circ} \mathrm{C}$ for the biodiesel-diesel blend with 30 vol.\% JME (Silitonga et al., 2013).

Biodiesel, also termed fatty acid methyl esters, generally has a lower heating value than petroleum-derived diesel due to its approximately $10 \mathrm{wt}$ \% lower content of elemental carbon. Liquid fuel, with its higher heating value, generally requires less fuel mass burning to attain the same output of engine power or heating energy (Leung et al., 2010). The reduced elemental carbon of biodiesel is almost complementarily replaced by oxygen content such that a higher rate of complete burning and much lower amounts of gaseous pollutants and toxic emissions such as particulate matter, carbon monoxide, and hydrocarbon are frequently observed with biodiesel (Palit et al., 2011). Fishing boat fuel A exhibited the highest, and biodiesel the lowest, heating value in Table 1. Hence, the heating value of blended fishing boat fuel B decreased more significantly than that of fishing boat fuel A with the increase in the weight proportion of biodiesel, as shown in Figure 3. Moreover, the heating values of fuels $A$ and $\mathrm{B}$ and their engine power outputs decreased by around 1.0 and $4.5 \%$, respectively, when blended with 25 wt. $\%$ biodiesel. Similar to fishing boat fuels, the heating value of the blend of diesel for road-based vehicles-biodiesel was found to decrease with the increase of biodiesel percentage (Oghenejoboh and Umukoro, 2011). Silitonga et al. (2013) observed that the heating value of diesel decreased by $10.7 \%$ from 45.825 to $40.901 \mathrm{MJ} / \mathrm{kg}$ after it was blended with 30 vol.\% refine palm oil biodiesel.

Biodiesel generally does not contain any sulfur compounds, and thus nearly no sulfur oxides are produced from the burning of biodiesel. In contrast, various sulfur contents frequently exist in crude oil and its derived fuel products. The sulfur compound contained in liquid fuel is prone to forming sulfur oxides that can unite with water vapor to produce sulfuric acids. The release of sulfuric acids into the environment can cause acid rain, which might result in ocean or land acidulation. The gaseous emission of sulfuric acids may be further condensed at an exhaust gas temperature that is lower than its corresponding dew point. When the

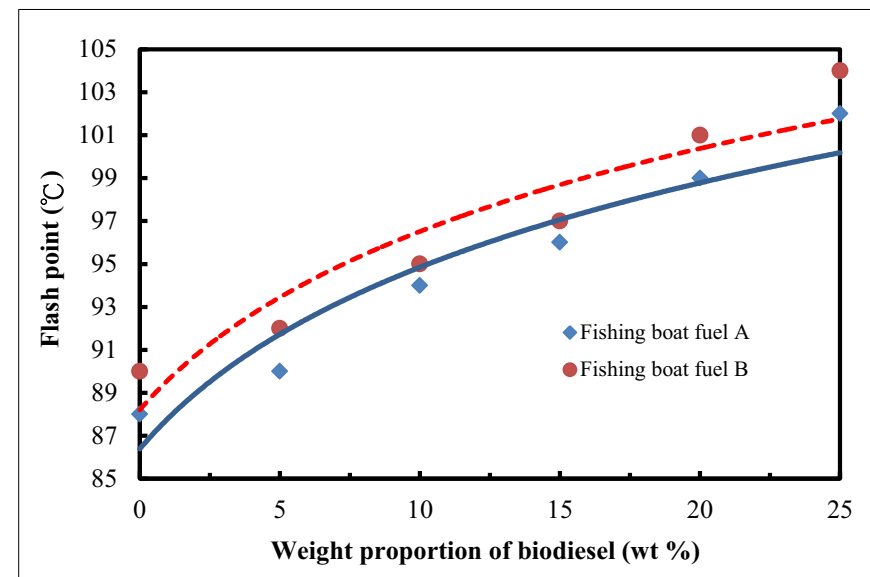

FIGURE 2 | Variation in flash point according to the weight proportion of biodiesel-blended in fishing boat fuels $A$ and $B$.

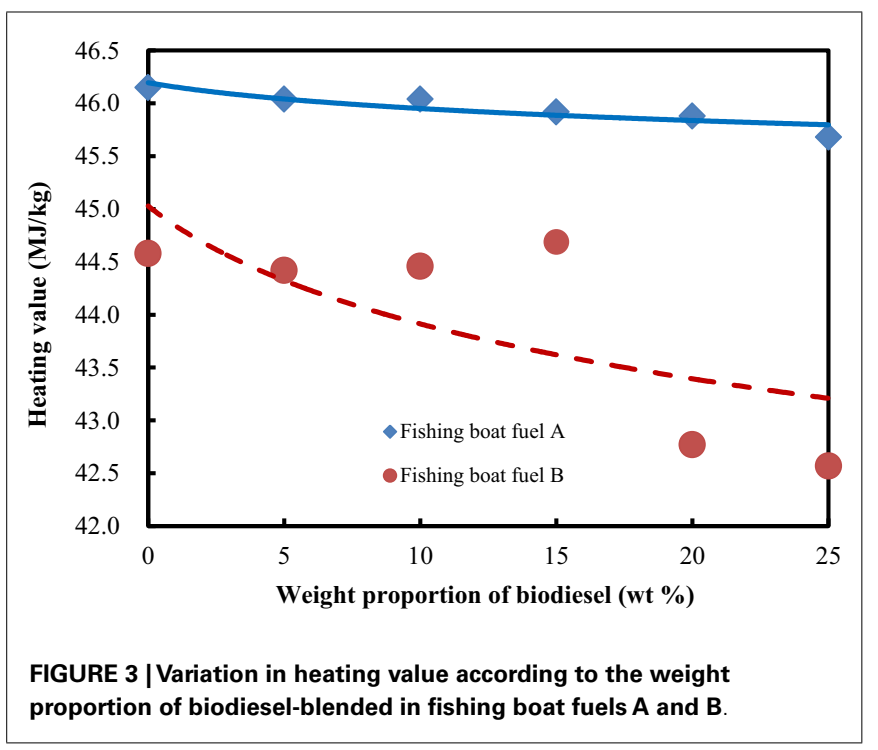

aqueous sulfuric acids adhere to the metallic materials of engines or furnaces, corrosion and even breakdown of the combustion equipment occur. Solid sulfate may also be produced from the combustion of sulfur-containing fuel and may be united with particulate matter. The replacement of petroleum-derived fuel with biodiesel that has no sulfur content is considered one of the most effective ways to reduce the environmental effects and equipment damage caused by sulfur oxides (Qi et al., 2010).

Fishing boat fuels $\mathrm{A}$ and $\mathrm{B}$ were found to have much higher sulfur contents, amounting to 0.293 and $0.951 \mathrm{wt} . \%$, respectively, than the biodiesel (Table 1). The sulfur contents of fuels A and B were up to 293 and 951 times, respectively, the sulfur content $(10 \mathrm{ppm})$ of SLSD for land-based diesel vehicles. The sulfur contents of the fishing boat fuels were found to decrease rather significantly with the increase in the weight proportion of biodiesel, as shown in Figure 4. Fuel B benefited much more than fuel A from the addition of biodiesel, in terms of sulfur reduction. 


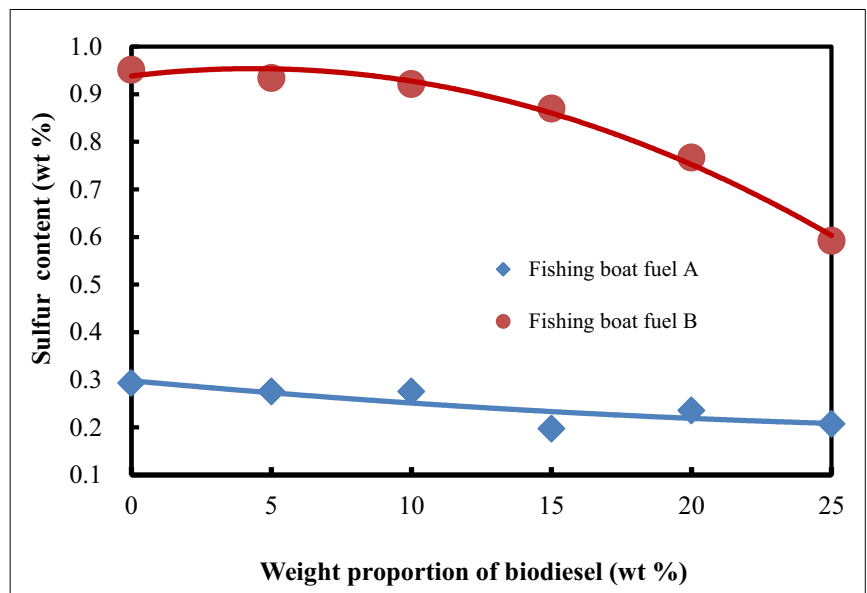

FIGURE 4 | Variation in sulfur content according to the weight proportion of biodiesel-blended in fishing boat fuels $A$ and $B$

The sulfur contents of fuels $\mathrm{B}$ and A decreased by as much as 37 and $33 \%$, respectively, by blending with $25 \mathrm{wt} . \%$ biodiesel. Diesel for road-based vehicles contains almost no sulfur content, which is $10 \mathrm{ppm}$ (milligrams per kilogram) maximum (European Committee for Standardization, 2009). Hence, the diesel-biodiesel blends have approximately the same sulfur contents as that of either diesel for road-based vehicles or biodiesel (Mushrush et al., 2013).

\section{CONCLUSION}

Biodiesel is a renewable clean alternative fuel for marine applications. The relatively higher fuel cost of biodiesel compared with fishing boat fuel is one major obstacle in developing biodiesel as an alternative fuel for marine vessels. The blending of fishing boat fuel with a lower proportion of biodiesel not only alleviates the high cost of biodiesel, but also reduces atmospheric pollution from shipping. The major experimental results can be summarized as follows:

1. Fishing boat fuel $\mathrm{B}$, which is a residual fuel, was found to have inferior fuel properties compared with those of biodiesel and fishing boat fuel A, including higher fuel sulfur content, kinematic viscosity, density and carbon residue. However, biodiesel has the lowest heating value and the highest flash point of the three tested fuels.

2. Liquid fuel with a higher flash point would enhance the safety of fuel transportation and storage. The addition of biodiesel considerably increases the flash points of the fishing boat fuels. The blending of $25 \mathrm{wt} . \%$ biodiesel was found to increase the flash point of fishing boat fuel B by $16 \%$.

3. The kinematic viscosity of fishing boat fuel $B$ was reduced much more significantly (by 63\%) than that of fishing boat fuel A by adding only $25 \mathrm{wt} . \%$ biodiesel, greatly reducing the heating and pumping energy required for fuel fluidity and atomization through engine nozzles.

4. Biodiesel blending caused a slight decrease in the heating values of the fishing boat fuels, by around 1.0 and $4.5 \%$ for fishing boat fuels A and B, respectively, with $25 \mathrm{wt} . \%$ biodiesel blending. However, a higher rate of complete burning and lower amounts of gaseous pollutants and toxic emissions were observed for fuel blended with biodiesel.

5. Biodiesel contains no sulfur content and does not produce oxides of sulfur or solid sulfate. Biodiesel blending is thus one effective way to curtail sulfur oxide emissions from marine vessels, which are generally fueled with residual heavy fuel oil with sulfur content as high as 951 times that of land-based diesel fuel. The sulfur contents of fishing boat fuels A and B were decreased significantly by 33 and $37 \%$, respectively, after blending with $25 \mathrm{wt}$ \% biodiesel.

\section{ACKNOWLEDGMENTS}

We acknowledge the receipt of financial support from the National Science Council of Taiwan, ROC, under project nos NSC97-2628E-019-016-MY2, NSC 100-2622-E-019-004-CC3, and NSC1002622-E-019-029-MY3.

\section{REFERENCES}

American Society for Testing and Materials (ASTM). (2005). ASTM D-129899e2: Standard Test Method for Density, Relative Density (Specific Gravity), or API Gravity of Crude Petroleum and Liquid Petroleum Products by Hydrometer Method. West Conshohocken, PA: American Society for Testing and Materials.

American Society for Testing and Materials (ASTM). (2010a). Standard Specification for Diesel Fuel Oils, ASTM D975-10b. West Conshohocken, PA: American Society for Testing and Materials.

American Society for Testing and Materials (ASTM). (2010b). Standard Specification for Diesel fuel Oil, Biodiesel Blend (B6 to B20), ASTM D7467-10. West Conshohocken, PA: American Society for Testing and Materials.

Atadashi, I. M., Aroua, M. K., and Aziz, A. A. (2010). High quality biodiesel and its diesel engine application: a review. Renew. Sustain. Energ. Rev. 14, 1999-2008. doi:10.1016/j.rser.2010.03.020

Benjumea, P., Agudelo, J., and Agudelo, A. (2008). Basic properties of palm oil biodiesel-diesel blends. Fuel 87, 2069-2075. doi:10.1016/j.fuel.2007.11.004

Chen, L. Y., Chen, Y. H., Hung, Y. S., Chiang, T. H., and Tsai, C. H. (2013). Fuel properties and combustion characteristics of Jatropha oil biodiesel-diesel blends. J. Taiwan Inst. Chem. Eng. 44, 214-220. doi:10.1016/j.jtice.2012.09.011

Corett, J. C., Wang, C., Winebrake, J. J., and Green, E. (2007). Allocation and Forecasting of Global Ship Emissions. Boston, MA: Clean Air Task Force.

Deniz, C., Kilic, A., and Civkaroglu, G. (2010). Estimation of shipping emissions in Candarli Gulf, Turkey. Environ. Monit. Assess. 71, 219-228. doi:10.1007/s10661009-1273-2

European Biodiesel Board (EBB). (2013). Available at: http://www.ebb-eu.org/stats. php (accessed on August 3, 2013).

European Committee for Standardization. (2009). Automotive Fuels-Diesel Requirements and Test Methods, EN 590:2009. Brussels: CEN.

Eyring, V., Kohler, H. W., van Aardenne, J., and Lauer, A. (2005). Emissions from international shipping: 1. The last 50 years. J. Geophys. Res. 110, D17305. doi:10.1029/2004JD005619

Leung, D. Y. C., Wu, X., and Leung, M. K. H. (2010). A review on biodiesel production using catalyzed transesterification. Appl. Energy 87, 1083-1095. doi:10.1016/j.apenergy.2009.10.006

Li, Z., Wu, Y., Yang, H., Cai, C., Zhang, H., Hashiguchi, K., et al. (2013). Effect of liquid viscosity on atomization in an internal-mixing twin-fluid atomizer. Fuel 103, 486-494. doi:10.1016/j.fuel.2012.06.097

Lin, C. Y., and Huang, T. H. (2012). Cost-benefit evaluation of using biodiesel as an alternative fuel for fishing boats in Taiwan. Mar. Pol. 36, 103-107. doi:10.1016/j.marpol.2011.04.002

Lin, C. Y., and Lin, Y. W. (2012). Fuel characteristics of biodiesel produced from a high-acid oil from soybean soap stock by supercritical-methanol transesterification. Energies 5, 2370-2380. doi:10.3390/en5072370 
Mejia, J. D., Salgado, N., and Orrego, C. E. (2013). Effect of blends of diesel and palm-castor biodiesels on viscosity, cloud point and flash point. Ind. Crops Prod. 43, 791-797. doi:10.1016/j.indcrop.2012.08.026

Mushrush, G. W., Hughes, J. M., and Willauer, H. D. (2013). Blends of soybean biodiesel with petroleum diesel: advantages. Ind. Eng. Chem. Res. 52, 1764-1768. doi: $10.1021 /$ ie $302865 \mathrm{x}$

Oghenejoboh, K. M., and Umukoro, P. O. (2011). Comparative analysis of fuel characteristics of bio-diesel produced from selected oil-bearing seeds in Nigeria. Eur. J. Sci. Res. 58, 238-246.

Palit, S., Chowdhuri, A. K., and Mandal, B. K. (2011). Environmental impact of using biodiesel as fuel in transportation: a review. Int. J. Glob. Warm. 3, 232-256. doi:10.1504/IJGW.2011.043421

Pulkrabek, W. W. (2004). “Thermochemistry and fuels," in Engineering Fundamentals of the Internal Combustion Engine, 2nd Edn (Singapore: Pearson Prentice-Hall Inc), 168-169.

Qi, D. H., Chen, H., Geng, L. M., and Bian, Y. Z. H. (2010). Experimental studies on the combustion characteristics of a direct injection engine fueled with biodiesel/diesel blends. Energy Convers. Manag. 51, 2985-2992. doi:10.1016/j. enconman.2010.06.042

Shang, Q., Jiang, W., Lu, H., and Liang, B. (2010). Properties of Tung oil biodiesel and its blends with 0\# diesel. Bioresour. Technol. 101, 826-828. doi:10.1016/j. biortech.2009.08.047
Silitonga, A. S., Masjuki, H. H., Mahlia, T. M. I., Ong, H. C., Chong, W. T., and Boosroh, M. H. (2013). Overview properties of biodiesel diesel blends from edible and non-edible feedstock. Renew. Sustain. Energ. Rev. 22, 346-360. doi:10.1016/j.rser.2013.01.055

Conflict of Interest Statement: The author declares that the research was conducted in the absence of any commercial or financial relationships that could be construed as a potential conflict of interest.

Received: 11 December 2013; paper pending published: 14 January 2014; accepted: 10 February 2014; published online: 24 February 2014.

Citation: Lin C-Y (2014) Blending biodiesel in fishing boat fuels for improved fuel characteristics. Front. Energy Res. 2:6. doi: 10.3389/fenrg.2014.00006

This article was submitted to Bioenergy and Biofuel, a section of the journal Frontiers in Energy Research.

Copyright (c) 2014 Lin. This is an open-access article distributed under the terms of the Creative Commons Attribution License (CC BY). The use, distribution or reproduction in other forums is permitted, provided the original author(s) or licensor are credited and that the original publication in this journal is cited, in accordance with accepted academic practice. No use, distribution or reproduction is permitted which does not comply with these terms. 